\title{
鉛ケイ酸塩ガラスの弾性的性質と短・中距離構造
}

\author{
吉本 護 曾我直弘
}

(京都大学 工学部 工業化学科)

\section{Elastic Properties and the Short- and Medium-Range Structures of Lead Silicate Glasses}

\author{
Mamoru YOSHIMOTO and Naohiro SOGA \\ $\left(\begin{array}{l}\text { Department of Industrial Chemistry, Faculty of Engineering, Kyoto University } \\ \text { Yoshida-hommachi, Sakyo-ku, Kyoto-shi } 606\end{array}\right)$
}

\begin{abstract}
The elastic moduli and their pressure and temperature derivatives of lead silicate glasses were measured by the cubic resonance method and pulse superposition method. Thermal expansion coefficients and heat capacities were also measured. The sound velocities, Young's modulus, shear modulus decreased monotonously with increasing PbO content, but the bulk modulus increased with increasing PbO content up to its maximum at about 50 mol\% PbO and then decreased remarkably. The compositional dependence of bulk modulus was interpreted based on the change in the role of Pb' ions in glass structure. That is, $\mathrm{Pb}^{2+}$ ions behave as a network modifier for $\mathrm{PbO}$ content $<50$ mol\% and as a network former for PbO content $>50 \mathrm{~mol} \%$. The short- and medium-range structures in lead silicate glasses were discussed in terms of the three-band theory using characteristic temperatures obtained from the specific heats. It was found that the medium-range order in lead silicate glasses increased with increasing $\mathrm{PbO}$ content. The elastic anomaly in fused silica with negative pressure and positive temperature derivatives disappeared with increasing $\mathrm{PbO}$ content. Lead silicate glasses with PbO content $>40$ mol\% showed no elastic anomaly. The characteristic temperature representing the intermolecular bonding of the glass network was found to affect the pressure and temperature derivatives of elastic moduli.

[Received January 6, 1986]
\end{abstract}

Key-words : Lead silicate glasses, Elastic properties, Three-band theory, Short- and medium-range structure, Elastic anomaly

\section{1. 緒 言}

鉛ケイ酸塩ガラスはガラス化領域が広く, 通常の溶融 法でも $\mathrm{PbO}$ を約 $75 \mathrm{~mol} \%$ 含有したガラスが作製で き1)，また水冷法により $\mathrm{PbO}$ 含有量 $95 \mathrm{~mol} \%$ までガラ ス化領域が広がることが報告されている21. 一方, 著者 らは超急冷双ロール法により通常の網目形成酸化物を含 まない鉛高含有ガラスも作製してきだ3.

このようなガラス化領域の広さや ESR スペクトルの 解析結果 ${ }^{4}$ から, $\mathrm{Pb}^{2+}$ イオンはガラス網目形成イオンと しての役割をもち得ると考えられる. したがってアルカ リケイ酸ガラスとは別に鉛ケイ酸塩ガラスもガラス構造 の本質を考えるうえで重要なガラスであるといえる。

鉛ケイ酸塩ガラスの構造に関する研究は従来から数多 く行われており ${ }^{5)-11)}$, その物性も種々調べられてい

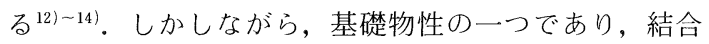
力と密接に関連している熱的及び弾性的性質に関する系 統的な研究はまだ十分ではなく，酸化鉛を多量に含むガ ラスの工学的特性を解明するうえでもこれらの物性を調 ベることは極めて重要であると思われる。

本研究においてはこの鉛ケイ酸塩ガラスについて弾性 率の組成, 圧力及び温度依存性, 並びに熱膨張係数, 熱 容量を調べ，その結果をガラス中における原子間結合力
とガラス構造の秩序性の面から解釈を試みたので報告す る.

\section{2. 実験方法及び結果}

\section{1 試料作製}

特級試薬の $\mathrm{PbO}$ 及び $\mathrm{SiO}_{2}$ を用い, 所定の組成 $\left(x \mathrm{PbO} \cdot(1-x) \mathrm{SiO}_{2}, x=0.33,0.40,0.50,0.58,0.67\right.$, 0.70) にひょう量したバッチを白金るつぼに入れ, 白金 のふたをして電気炉内で $900^{\circ} \sim 1400^{\circ} \mathrm{C}$ にて約 1〜3 時間 かくはん溶融した。清澄を確認した融液をステンレス製 ブロックの鋳型に流し込み, 弾性率測定用として一辺約 $10 \mathrm{~mm}$ の立方体に, 熱膨張测定用としては直径 $3 \mathrm{~mm}$, 長さ $30 \mathrm{~mm}$ の棒状にそれぞれ成形した. 試料を徐冷点 付近の温度 $\left(300^{\circ} \sim 400^{\circ} \mathrm{C}\right)$ で約 10 時間保持した後, 研 磨して測定に供した。

\section{2 弾性率}

\subsection{1 測定法}

弾性率の測定にはマイクロコンピューターを接続した 立方体共振装置を使用した。共振法は一定の形状をもつ た試料の力学的スペクトロスコピーであって, 共振スペ クトルが弾性体試料の形状と弾性定数に依存することを 利用した方法である ${ }^{15)}$. 測定装置を図1に示した。なお 


\section{装置については既報 ${ }^{16}$ に詳しい。}

\subsection{2 弾性率の組成依存性}

$\mathrm{PbO}-\mathrm{SiO}_{2}$ 系ガラスの縦波音速 $V_{1}$, 横波音速 $V_{\mathrm{t}}$ の組 成変化を図 2 に示した。 またポアッソン比，ヤング率， 体積弾性率, 剛性率のそれぞれの組成変化をまとめて図 3 に示した。図2, 図 3 より音速, ヤング率, 剛性率は $\mathrm{PbO}$ 含有量の増加とともにほぼ単調に減少し,ポアッ ソン比は単調に増加することが分かる. しかし体積弾性 率の組成依存性は単調な変化を示さず, $\mathrm{PbO}=30$ $\mathrm{mol} \%$ 付近で極小值, $50 \mathrm{~mol} \%$ 付近で極大值を示した.

\subsection{3 弾性率の圧力係数}

共振法では加圧下測定が困難なので弾性率の圧力変化 の測定には超音波干渉法を用いた。測定方法の概略を図 4 に示した。一辺約 $10 \mathrm{~mm}$ の立方体試料を用い, 両面

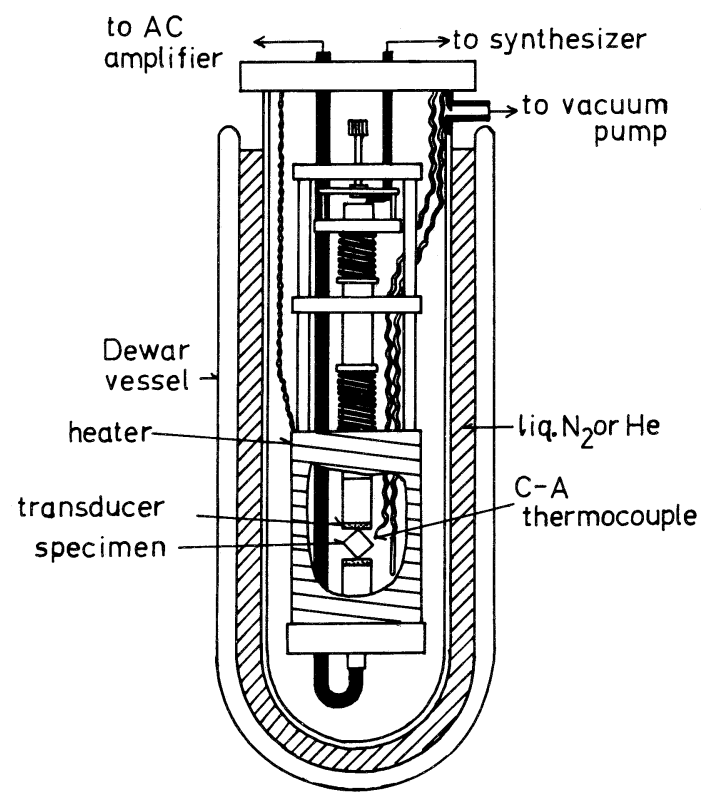

Fig. 1. Measurement cell of the elastic modulus and its temperature dependence by the cubic resonance method.

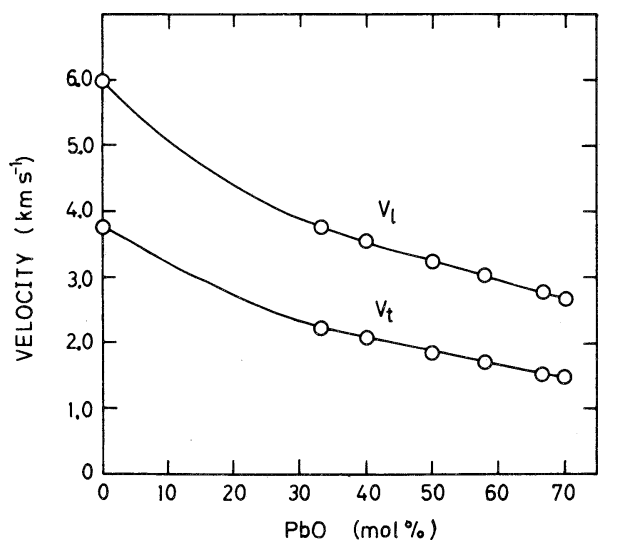

Fig. 2. Longitudinal and shear wave velocity versus $\mathrm{PbO}$ content for $\mathrm{PbO}-\mathrm{SiO}_{2}$ glasses.
研磨した一面に $20 \mathrm{MHz}$ の X カットあるいは $\mathrm{Y}$ カット の水晶発振子をとりつけて測定を行った。測定原理及び 操作は既報 ${ }^{17)}$ と同様である.

0 100 MPa の圧力範囲で約 $10 \mathrm{MPa}$ の間隔ごとに加 圧し, 各静水圧下で少なくとも 10 分間維持した後, 干 渉周波数 $f$ を測定した. 干渉周波数の圧力係数を用い て，次式により弾性率の圧力係数を求めた ${ }^{18}$.

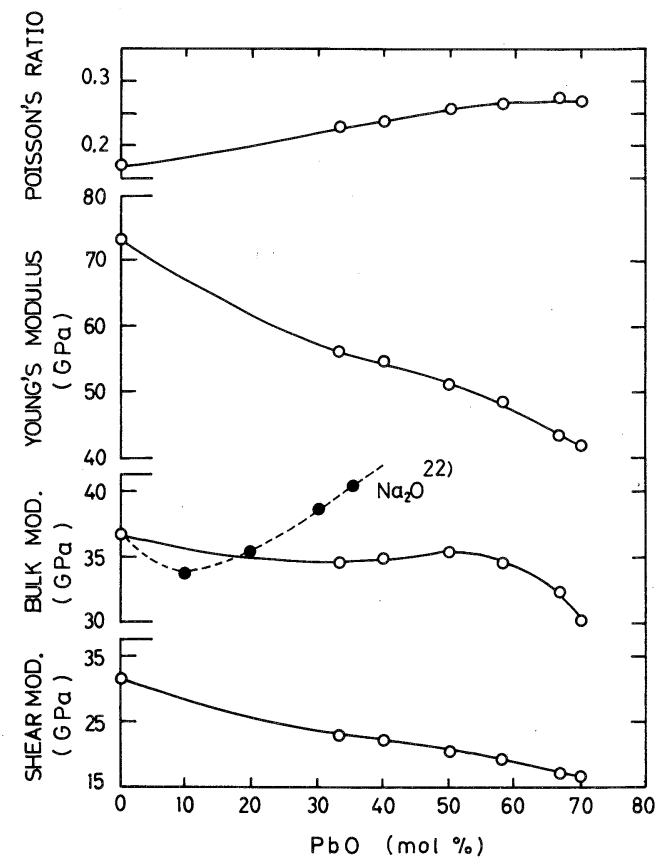

Fig. 3. Elastic moduluses versus $\mathrm{PbO}$ content for $\mathrm{PbO}-\mathrm{SiO}_{2}$ glasses.

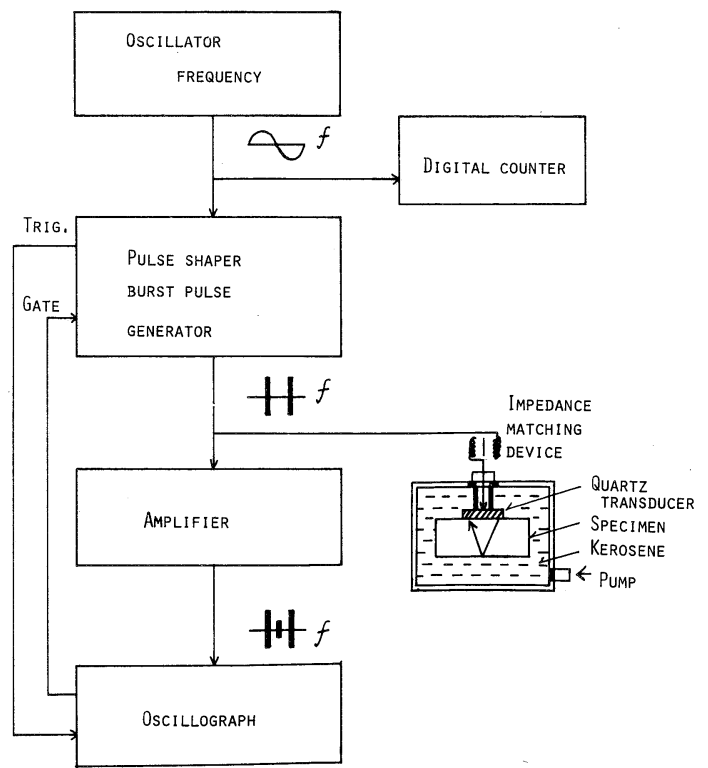

Fig. 4. Block diagram of the pulse superposition method. 


$$
\begin{aligned}
\frac{\mathrm{d} G}{\mathrm{~d} P}= & 2 G\left(\frac{\mathrm{d}\left(\frac{f}{f_{0}}\right)_{\mathrm{t}}}{\mathrm{d} P}\right)+\frac{G}{3 K}\left(1+3 \alpha_{\mathrm{L}} \gamma_{\mathrm{th}} T\right) \\
\frac{\mathrm{d} K}{\mathrm{~d} P}= & 2 \rho V_{1}^{2}\left(\frac{\mathrm{d}\left(\frac{f}{f_{0}}\right)_{1}}{\mathrm{~d} P}\right)-\frac{8}{3} G\left(\frac{\mathrm{d}\left(\frac{f}{f_{0}}\right)_{\mathrm{t}}}{\mathrm{d} P}\right) \\
& +\frac{1}{3}\left(1+3 \alpha_{\mathrm{L}} \gamma_{\mathrm{th}} T\right)
\end{aligned}
$$

ここで $\rho$ は密度， $\alpha_{\mathrm{L}}$ は線熱膨張係数， $G$ 及び $K$ はそれ ぞれ剛性率，体積弾性率を示し， $f_{0}$ は無加圧下での干 渉周波数, $\gamma_{\mathrm{th}}$ は熱的グリューナイゼン定数である.

$\gamma_{\mathrm{th}}$ は線熱膨張係数 $\alpha_{\mathrm{L}}$, 体積弾性率 $K$, 定圧比熱 $C_{\mathrm{P}}$, 平均原子容 $V$ を用いて次のように表される。

$$
\gamma_{\mathrm{th}}=\frac{3 \alpha_{\mathrm{L}} K V}{C_{\mathrm{P}}}
$$

干渉周波数 $f$ の圧力変化は直線的であったのでその 傾きを $f$ の圧力係数とし，（1），（2）式により各弾性 率の圧力係数を求めた。その結果を図 5 に示した。図 5 から分かるように $\mathrm{SiO}_{2}$ ガラスは, 多くの酸化物ガラス にみられるような正の圧力係数ではなく，負の圧力係数 をもち，いわゆる弾性的異常を示す． $\mathrm{SiO}_{2}$ ガラスのほ かに $\mathrm{BeF}_{2}$ ガラス, $\mathrm{GeO}_{2}$ ガラスなどが弾性的異常を示 すことが知られている(19),201.

弾性率の圧力係数は $\mathrm{PbO}$ 含有量が増加するにつれて 負から正へと変化し, $\mathrm{SiO}_{2}$ ガラスでみられた弾性的異 常は消失していく.

\subsection{4 弾性率の温度係数}

弾性率の温度変化の測定は図 1 に示すように試料セル をガラス製容器に入れ, $100 \mathrm{mmHg}$ の $\mathrm{He}$ を封入した後,
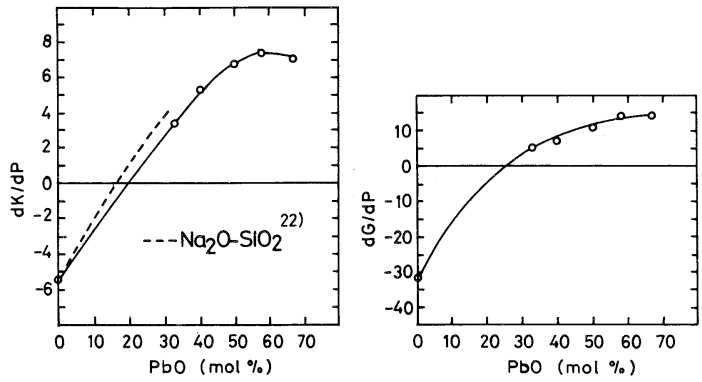

Fig. 5. Pressure derivatives of the bulk modulus $K$ and the shear modulus $G$ for $\mathrm{PbO}-\mathrm{SiO}_{2}$ glasses.
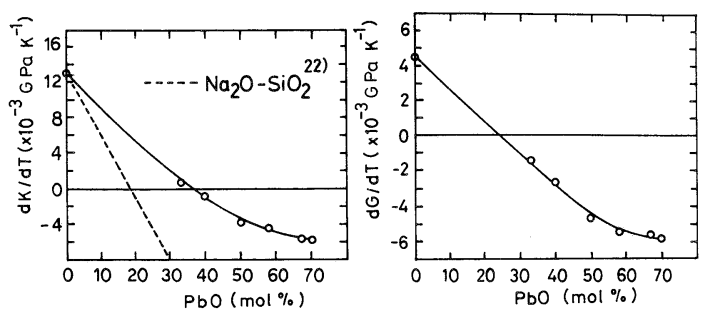

Fig.6. Temperature derivatives of the bulk modulus $K$ and the shear modulus $G$ for $\mathrm{PbO}-\mathrm{SiO}_{2}$ glasses.
80 ～ $300 \mathrm{~K}$ の温度範囲に調節することにより行った． 弾 性率の温度係数は横波音速 $V_{\mathrm{t}}$ と縦波音速 $V_{1}$ の温度係 数を含む次式により求められる.

$$
\begin{aligned}
& \frac{\mathrm{d} G}{\mathrm{~d} T}=2 \rho V_{\mathrm{t}}\left(\frac{\mathrm{d} V_{\mathrm{t}}}{\mathrm{d} T}\right)^{\prime}-3 \alpha_{\mathrm{L}} G \\
& \frac{\mathrm{d} K}{\mathrm{~d} T}=2 \rho\left\{V_{\mathrm{l}}\left(\frac{\mathrm{d} V_{\mathrm{l}}}{\mathrm{d} T}\right)^{\prime}-\frac{4}{3} V_{\mathrm{t}}\left(\frac{\mathrm{d} V_{\mathrm{t}}}{\mathrm{d} T}\right)^{\prime}\right\}-3 \alpha_{\mathrm{L}} K \\
& \frac{1}{V_{i}}\left(\frac{\mathrm{d} V_{i}}{\mathrm{~d} T}\right)^{\prime}=\alpha_{\mathrm{L}}+\frac{1}{V_{i}}\left(\frac{\mathrm{d} V_{i}}{\mathrm{~d} T}\right)(i=t, l)
\end{aligned}
$$

音速の温度変化を 100 ～ $300 \mathrm{~K}$ で測定したところ，こ の温度範囲ではほぼ直線的に変化した。そこでその傾き を音速の温度係数とした。（4)，（5）式から剛性率 $G$, 体積弾性率 $K$ の温度係数を求め, $\mathrm{PbO}$ 含有量に対して プロットしたのが図6である.多くの酸化物ガラスの弾 性率の温度係数は負の值を示すが，圧力係数と同様に $\mathrm{SiO}_{2}$ ガラス, $\mathrm{BeF}_{2}$ ガラス, $\mathrm{GeO}_{2}$ ガラスなどは正の值 をもち弾性的異常を示す。図 6 より明らかなように $\mathrm{PbO}$ 含有量が増加するにつれて温度係数は正から負へ と変化し, $\mathrm{SiO}_{2}$ ガラスでみられた弾性的異常は消失し ていく.

上述の弾性率の圧力係数及び温度係数の組成変化の結 果から, $\mathrm{PbO}-\mathrm{SiO}_{2}$ 系ガラスでは $\mathrm{PbO}$ 含有量が増加す

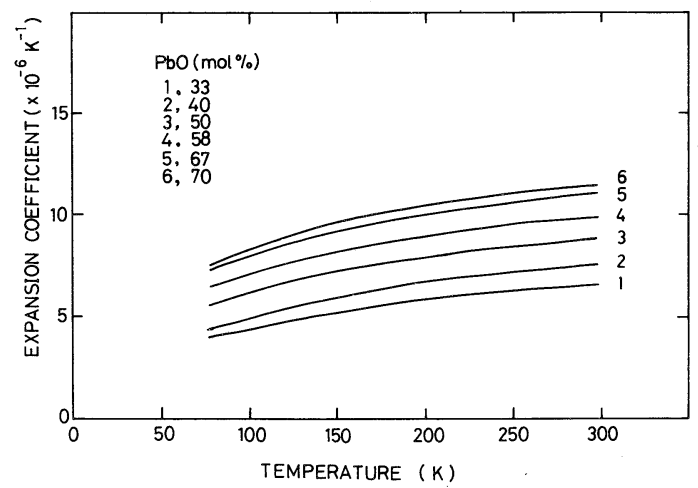

Fig. 7. Temperature dependence of thermal expansion coefficients for $\mathrm{PbO}-\mathrm{SiO}_{2}$ glasses.

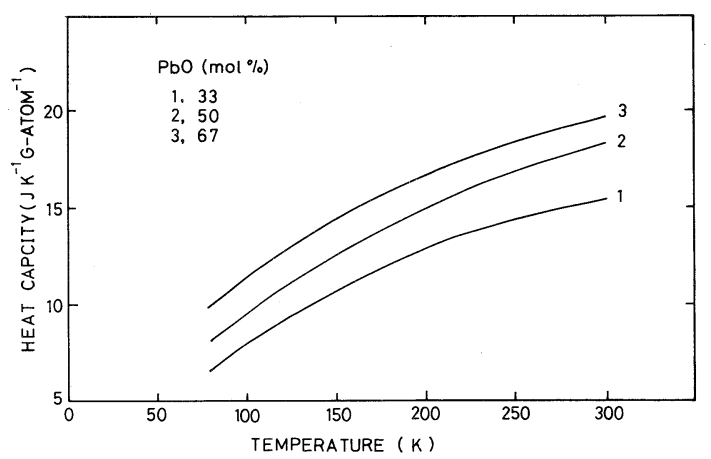

Fig. 8. Temperture dependence of heat capacities for $\mathrm{PbO}-\mathrm{SiO}_{2}$ glasses. 
Table 1. Elastic properties of $\mathrm{PbO}-\mathrm{SiO}_{2}$ glasses.

\begin{tabular}{|c|c|c|c|c|c|c|c|c|c|}
\hline $\mathrm{PbO}$ & content & moli & 0 & 33 & 40 & 50 & 58 & 67 & 70 \\
\hline$\rho$ & & $\mathrm{g} \mathrm{cm}^{-3}$ & 2.201 & 4.600 & 5.151 & 5.964 & 6.564 & 7.168 & 7.321 \\
\hline$v_{t}$ & & $\mathrm{~km} \mathrm{~s}^{-1}$ & 3.765 & 2.230 & 2.077 & 1.845 & 1.711 & 1.541 & 1.504 \\
\hline $\mathrm{v}_{1}$ & & $\mathrm{~km} \mathrm{~s} \mathrm{~s}^{-1}$ & 5.966 & 3.765 & 3.538 & 3.235 & 3.026 & 2.771 & 2.672 \\
\hline $\mathrm{K}^{2}$ & & $\mathrm{GPa}$ & 36.76 & 34.71 & 34.83 & 35.33 & 34.49 & 32.33 & 30.16 \\
\hline G & & $\mathrm{GPa}$ & 31.33 & 22.87 & 22.22 & 20.30 & 19.21 & 17.03 & 16.57 \\
\hline $\mathrm{Y}$ & & $\mathrm{GPa}$ & 73.20 & 56.25 & 54.97 & 51.11 & 48.62 & 43.45 & 42.01 \\
\hline$\sigma$ & & & 0.169 & 0.230 & 0.237 & 0.259 & 0.265 & 0.276 & 0.268 \\
\hline & $\rho ; \mathrm{De}$ & nsity & & & & \multicolumn{3}{|c|}{$\mathrm{K}$; Bulk modulus } & \\
\hline & $v_{t} ; S h$ & ear wave & veloc & & & \multicolumn{3}{|c|}{ G ; Shear modulus } & \\
\hline & $\mathrm{V}_{1}$; LO & ngitudir & l wav & velo & & \multicolumn{3}{|c|}{ Y ; Young's modulus } & \\
\hline
\end{tabular}

Table 2. Pressure and temperature dependence of elastic properties of $\mathrm{PbO}-\mathrm{SiO}_{2}$ glasses.

\begin{tabular}{|c|c|c|c|c|c|c|c|c|}
\hline \multicolumn{2}{|c|}{$\mathrm{PbO}$ content mol\% } & 0 & 33 & 40 & 50 & 58 & 67 & 70 \\
\hline $\mathrm{dv}_{t} / \mathrm{dP}$ & $\begin{array}{c}\mathrm{km} \mathrm{s} \mathrm{s}^{-1} \mathrm{GPa}^{-1} \\
\left(\mathrm{x} 10^{-1}\right)\end{array}$ & -2.34 & -0.06 & 0.02 & 0.23 & 0.39 & 0.41 & --- \\
\hline $\mathrm{dv}_{1} / \mathrm{dP}$ & $\begin{array}{c}\mathrm{km} \mathrm{s}^{-1} \mathrm{GPa}^{-1} \\
\left(\mathrm{x} 10^{-1}\right)\end{array}$ & $-4 \cdot 32$ & 0.64 & 1.24 & 1.69 & 1.89 & 1.87 & -- \\
\hline $\mathrm{dK} / \mathrm{dP}$ & & -5.18 & 3.36 & 5.46 & 6.86 & 7.36 & 7.25 & --- \\
\hline $\mathrm{dG} / \mathrm{dP}$ & & -3.03 & 0.54 & 0.69 & 1.07 & 1.43 & 1.43 & -- \\
\hline $\mathrm{dV}_{\mathrm{t}} / \mathrm{dT}$ & $\begin{array}{c}\mathrm{km} \mathrm{s}^{-1} \mathrm{~K}^{-1} \\
\left(\mathrm{x} 10^{-4}\right)\end{array}$ & 2.70 & -0.50 & -1.04 & -1.90 & -2.20 & -2.29 & -2.46 \\
\hline $\mathrm{dv}_{1} / \mathrm{dT}$ & $\begin{array}{c}\mathrm{km} \mathrm{s}^{-1} \mathrm{~K}^{-1} \\
\left(\mathrm{x} 10^{-4}\right)\end{array}$ & 7.31 & -0.05 & -0.81 & -2.22 & -2.53 & -2.88 & -3.06 \\
\hline $\mathrm{dK} / \mathrm{dT}$ & $\begin{array}{l}\text { GPa } K^{-1} \\
\left(x 10^{-3}\right)\end{array}$ & 13.20 & 0.56 & -0.79 & -3.91 & -4.43 & -5.75 & -5.75 \\
\hline $\mathrm{dG} / \mathrm{dT}$ & $\begin{array}{l}\mathrm{GPa} \mathrm{K}^{-1} \\
\left(\mathrm{x} 10^{-3}\right)\end{array}$ & 4.43 & -1.48 & -2.70 & -4.73 & -5.52 & -5.59 & -5.97 \\
\hline
\end{tabular}

るにつれて弾性的挙動は正常な方に向かうといえる。

なお音速, 種々の弾性率, 密度の各值を表 1 に, 弾性 率の温度及び圧力係数の值を表 2 にそれぞれ示した。

\section{3 熱膨張及び熱容量}

$\mathrm{PbO}-\mathrm{SiO}_{2}$ 系ガラスの幾つかの組成の線熱膨張係数 $\alpha_{\mathrm{L}}$, 熱容量 $\mathrm{C}_{\boldsymbol{p}}$ の $80 \sim 300 \mathrm{~K}$ の範囲の温度変化を図 7, 図 8 に示した。密度，熱膨張係数，熱容量の測定法は既 報 ${ }^{21)}$ と同じなので省略する。

\section{3. 考察}

\section{1 弾性率の組成依存性}

実験結果の章で述べたように $\mathrm{PbO}-\mathrm{SiO}_{2}$ 系ガラスの 体積弾性率の組成依存性は極小值や極大值をもつ複雑な 挙動をしている。図 3 の点線で示したのは Manghnani ${ }^{221}$ による $\mathrm{Na}_{2} \mathrm{O}-\mathrm{SiO}_{2}$ 系ガラスの場合のデー夕（横軸は $\mathrm{Na}_{2} \mathrm{O}(\mathrm{mol} \%)$ 含有量) であるが，やはり単調减少はせず 極小值をもつ。これらの組成変化は，（1）Si-O 結合 よりも弱い結合力をもつ網目修飾イオンの導入によって 平均的な結合力が弱まる効果と, (2) 網目修飾イオン が Si-O 骨格内の空げきを埋める効果という二つの効果
の競争の結果を反映したものと思われる.すなわち, ( 1 ) の効果は体積弾性率を減少させるが，（2）の効果は逆 に増加させる働きを行う。 $\mathrm{PbO}$ 含有量の少ないときは （1）の効果が支配的であるが， $\mathrm{PbO}$ 含有量増加と之 もに（2）の効果が大きくなり，その結果 $\mathrm{PbO}=30$ $\mathrm{mol} \%$ 付近で極小值を生じたと考えられる. $\mathrm{PbO}$ 含有 量が $50 \mathrm{~mol} \%$ を超えると後述のように $\mathrm{Pb}^{2+}$ イオンが 網目の中に組み込まれるようになり，（2）の効果はな くなり（1）の効果が再び支配的となるため急激に減少 するものと思われる。このことは $\mathrm{PbO}$ 含有量が 50 $\mathrm{mol} \%$ を超えると $\mathrm{Pb}-\mathrm{O}$ 結合もガラス網目骨格を形成 していくといわれている変化 ${ }^{23)}$ 対応するものである. この変化は体積弾性率と平均原子容との関係を示した図 9 に明りょうに表れている. $\mathrm{PbO}$ が $33 \mathrm{~mol} \%$ から 50 $\mathrm{mol} \%$ までは平均原子容はあまり変化しないが， 50 mol\% を超えると大きく変化し, それに伴い体積弾性率 も大きく減少している．つまり 30〜 $50 \mathrm{~mol} \%$ の領域で は導入された $\mathrm{PbO}$ は（2）の効果に使われ，Si-O 網 目内の結合力の減少を上まわる内部エネルギーの増加が 表れ，その結果弾性率は上昇するものと考えられる。こ 


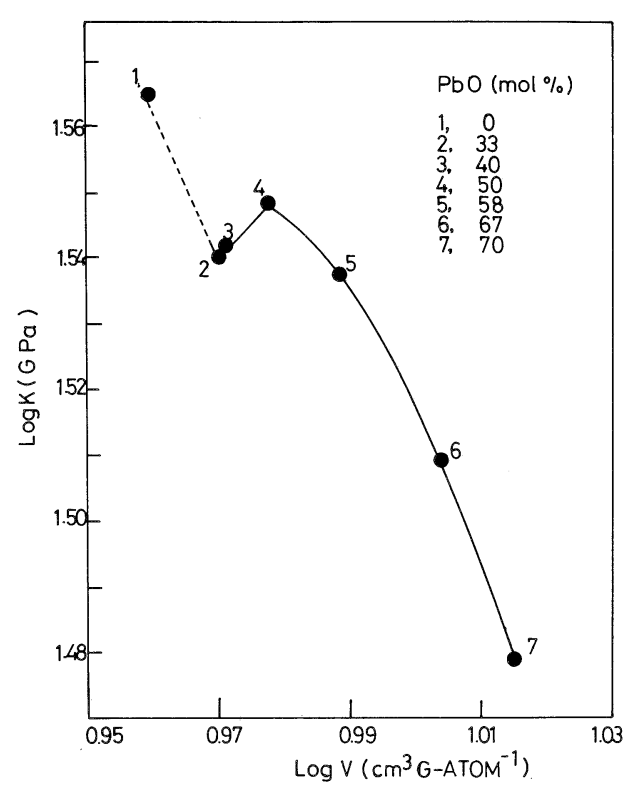

Fig. 9. $\log K$ versus $\log V$ plot for $\mathrm{PbO}-\mathrm{SiO}_{2}$ glasses. $K$ : bulk modulus, $V$ : mean atomic volume.

れに対し， $50 \mathrm{~mol} \%$ 以上で平均原子容が急増すること は Si-O 網目内に PbO が組み込まれることを示してお り, その結果 (1) の効果が大きく表れ, 体積弾性率は 大きく減少するものと考えられる.

次にこのような弾性率の組成依存性と3-バンド理論か ら求められる結合力との対応を考察する。3-バンド理論 は既報のようにガラス構造の結合力や構造の秩序性につ いて有用な知見を与えるが24)，そのもととなるのは比熱 の温度依存性から次式により求められる三つの特性温度 である。

$$
\begin{aligned}
C_{\mathrm{v}}= & 3 R \frac{T}{\theta_{1}} \int_{\theta_{3} / T}^{\theta_{1} / T} \frac{x^{2} e^{x}}{\left(e^{x}-1\right)^{2}} \mathrm{~d} x \\
& +\frac{9 R T}{\theta_{3}^{3}} \int_{0}^{\theta_{3} / T} \frac{x^{4} e^{x}}{\left(e^{x}-1\right)^{2}} \mathrm{~d} x \\
& +3 R\left\{\frac{\left(\frac{\theta_{\mathrm{E}}}{T}\right)^{2} e^{\theta_{\mathrm{E}} / T}}{\left(e^{\theta_{\mathrm{E}} / T}-1\right)^{2}}\right\}
\end{aligned}
$$

ここで $C_{\mathrm{v}}$ は定積比熱, $R$ は気体定数であり, $\theta_{1}, \theta_{3}$, $\theta_{\mathrm{E}}$ は特性温度を示す。

この理論では酸化物ガラスのように網目形成酸化物と 修飾酸化物より成り立っている物質の結合力をただ一つ のデバイ特性温度で表すことは難しいので, 次に示すよ うな三つの特性温度で代表される結合力より成り立って いると考える。

（1）修飾イオンと網目骨格アニオン間の結合力に相 当する特性温度, $\theta_{\mathrm{E}}$,

（2）網目骨格間の結合，すなわち分子間結合に相当 する特性温度, $\theta_{3}$,
（3）網目骨格内の原子間結合力に相当する特性温 度, $\theta_{1}$.

また $\theta_{1} / \theta_{3}$ の比に着目し, これがガラス中の格子振動 の繰り返し単位の大きさを示すものと考えると, $\theta_{1} / \theta_{3}$ が大きいほどつまり $\theta_{1}$ と $\theta_{3}$ の值が離れるほど, より乱 れた状態となることを示唆する ${ }^{24)}$. 例えば $\mathrm{SiO}_{2}$ ガラス では $\theta_{1}$ は $\mathrm{Si}-\mathrm{O}$ の原子間結合力に対応し, $\theta_{3}$ は $\mathrm{SiO}_{4}$ 四 面体で形成される六員環等の多員環同士の結合力すなわ ち骨格間の結合力に対応すると考えられる。実際求めら れた $\theta_{1}$ の值は $1550 \mathrm{~K}$ でイオン半径と電荷より類推した 值とよく一致し, また $\theta_{3}$ は $150 \mathrm{~K} て ゙$ 繰り返し単位の大 きさから考えても妥当な值である ${ }^{24)}$. これに $\mathrm{Na}_{2} \mathrm{O}$ など の修飾イオンを導入すると $\theta_{1}$ は減少するが， $\theta_{3}$ は増加 して， $\theta_{1} / \theta_{3}$ の値は 3 に収束した。これは $\mathrm{Na}^{+}$の導入に より Si-O 結合は弱められ，一方で骨格が切断されるた め構造単位が小さくなり, 乱れた構造から秩序のある構 造へ移るという考え方に対応する. また $\theta_{\mathrm{E}}$ は組成によ り大きく変化せず, イオン半径と電荷から計算した值と ほぼ同じ $230 \mathrm{~K}$ の值を示し, 網目修飾イオンとして $\mathrm{Na}-\mathrm{O}$ 結合は骨格に独立な Einstein 型振動をするとみ なせることが分かった。

さて $\mathrm{PbO}-\mathrm{SiO}_{2}$ 系ガラスの比熱を 3 -バンド理論によ り解析したところ, 他のケイ酸塩ガラスと同様, 上述の 三つのタイプの結合と関係する三つの特性温度 $\theta_{1}, \theta_{3}$, $\theta_{\mathrm{E}}$ によってある程度表せることが分かった。これら特 性温度の組成変化を図 10 に示す。 $\theta_{1}$ は $\mathrm{PbO}$ 含有量の 増加とともに減少しており, $\mathrm{Pb}^{2+}$ の導入によって $\mathrm{Si}-\mathrm{O}$ 結合が弱められることが分かる。 $\theta_{3}$ は $\mathrm{PbO}$ 導入により 単調に増加していく。したがって $\theta_{1} / \theta_{3}$ の比は $\mathrm{PbO}$ 導 入により小さくなっていくことになり, $\mathrm{PbO}-\mathrm{SiO}_{2}$ 系ガ ラスの乱れた構造は $\mathrm{PbO}$ 導入によって減少していくと

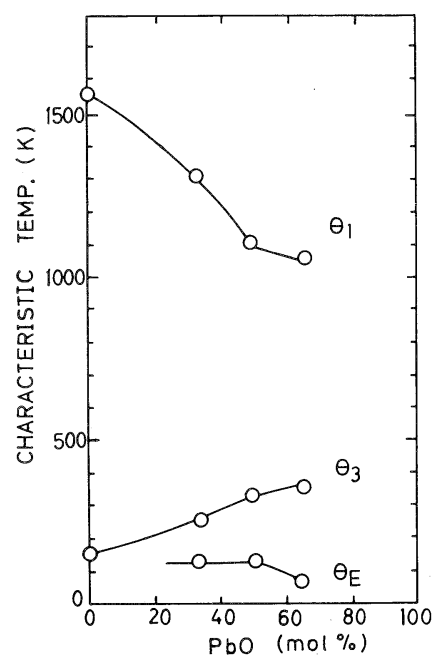

Fig. 10. Characteristic temperatures versus $\mathrm{PbO}$ content for $\mathrm{PbO}-\mathrm{SiO}_{2}$ glasses. 
考えられる.

もう一つの特性温度である $\theta_{\mathrm{E}}$ は $\mathrm{PbO}$ 含有量が 50 $\mathrm{mol} \%$ までは組成に依存しないで一定值をとり, 前述の $\mathrm{Na}_{2} \mathrm{O}$ と同様独立な振動をする網目修飾イオンとみなす 3 -バンド理論が適用できることを示しているが，50 $\mathrm{mol} \%$ を超えると大きく減少し， $\mathrm{Pb}-\mathrm{O}$ 結合が網目骨格 に独立な Einstein 型特性温度とみなし難くなることを 示している．言い換えると，PbO 含有量が $50 \mathrm{~mol} \%$ を 超えると $\mathrm{Pb}^{2+}$ は網目修飾イオンではなく，網目の中に 組み込まれた形で挙動することを示唆している.

\section{2 弾性率の圧力係数及び温度係数}

3.1 節で述べたように弾性率の組成依存性は結合力の 組成依存性と密接に関連している。またガラスに静水圧 をかけたときの弾性率の圧力係数もやはり結合力と関係 しており，一般に結合力が弱いほじ大きな正の值をもつ ことが知られている ${ }^{20)}$. しかしながら従来では弾性率の 圧力係数については一つのデバイ温度で表せるような物 質を対象とした議論を適用しているため, その組成依存 性を定量的に説明するに至っていない，特に酸化物ガラ スの代表である $\mathrm{SiO}_{2}$ ガラスは負の圧力係数といった弾 性的異常を示すが，その原因を従来の取り扱いで説明す ることは極好困難である。そこでここでは 3 -バンド 理論より導かれた各特性温度が圧力に対してビのような 依存性を示すかといった観点から考察を試みる.

Jorgensen ${ }^{25)}$ の $\alpha$-石英の圧縮機構によると, 圧縮は各 四面体を連結している架橋酸素原子を中心とした相対的 回転により起こり，各四面体を形成している堅固な $\mathrm{Si}-\mathrm{O}$ 結合はほとんど変化しないといわれている。この ことは $\mathrm{SiO}_{2}$ ガラスにもあてはまり，特性温度をもとに 考えると $\theta_{1}$ は $1550 \mathrm{~K}$ と高く, $\theta_{3}$ は $150 \mathrm{~K}$ と低いため, 第 1 近似として $\theta_{1}$ に相当する網目骨格内結合は圧力の 影響を受けにくく， $\theta_{3}$ に相当する骨格間結合が圧力に より大きく変化するとみなせる．これをもう少し定量的 に取り扱う之次のようになる。

結晶の非調和性を表す重要なパラメーターとしてグ リューナイゼン定数 $\gamma$ があるが, これは振動数の体積 微分として次のように定義される。

$$
\gamma=\frac{\sum_{i} C_{i} \gamma_{i}}{\sum_{i} C_{i}}, \quad \gamma_{i}=-\left(\frac{\operatorname{dln} \nu_{i}}{\operatorname{dln} V}\right)
$$

ここで $\gamma_{i}$ は振動数 $\nu_{i}$ に対して定められるもので， $C_{i}$ は モード $\nu_{i}$ の寄与する比熱である。

（８）式における振動モード $\nu_{i}$ を 3-バンド理論から得 られる特性温度 $\theta_{i}$ に関係づけると次のようになる。

$$
\gamma=\frac{V}{\sum_{i} C_{i}}\left(\sum_{i} \frac{C_{i}}{\theta_{i}} \frac{\mathrm{d} \theta_{i}}{\mathrm{~d} V}\right)(i=1,3, E)
$$

(9) 式の括弧の中の三つの項のうちで $\theta_{1}$ は $\mathrm{Si}-\mathrm{O}$ 結 合という強くて方向性のある結合に関係しているので, $\mathrm{d} \theta_{1} / \mathrm{d} V$ は他の二つに比べてその寄与は無視できると考 えられる。 また $\mathrm{SiO}_{2}$ ガラスの場合には $C_{\mathrm{E}}=0$ であるの で結局次のようになる.

$$
\gamma_{\mathrm{sio}_{2}} \simeq-\frac{V}{\sum_{i} C_{i}} \frac{C_{3}}{\theta_{3}} \frac{\mathrm{d} \theta_{3}}{\mathrm{~d} V}
$$

一方，実際の $\gamma$ の值を近似的に見積もる手段として 2.2 節で述べた $\gamma_{\mathrm{th}}$ のほかに横波, 縦波の 2 種類の弾性波 モードを考慮した $\gamma_{\mathrm{e}}$ が極低温以外の温度域に対して次 のように与えられている26!

$$
\begin{aligned}
& \gamma_{\mathrm{e}}=\frac{\gamma_{1}+\gamma_{\mathrm{t}}}{3} \\
& \gamma_{\mathrm{t}}=\frac{1}{3}+K\left(\frac{\mathrm{d} \ln V_{\mathrm{t}}}{\operatorname{dln} P}\right) \\
& \gamma_{\mathrm{t}}=\frac{1}{3}+K\left(\frac{\mathrm{d} \ln V_{\mathrm{t}}}{\operatorname{dn} P}\right)
\end{aligned}
$$

ここで $V_{\mathrm{l}}, V_{\mathrm{t}}$ はそれぞれ縦波音速，横波音速であり $K$ は体積弾性率である。

$\gamma_{\text {th }}$ はすべての振動モードが等しいと仮定した場合の 近似であるのに対し， $\gamma_{\mathrm{e}}$ は 2 種類の振動モードを考慮 している点が違う。

本研究で得られた弾性的性質を用いて $\gamma_{\mathrm{e}}$ を求める之 図 11 に示すようになり， $\mathrm{SiO}_{2}$ ガラスで負の值をもち， $\mathrm{PbO}$ 含有量が増加するにつれて負から正へと変化し, $\mathrm{PbO}$ が $50 \mathrm{~mol} \%$ 以上になると一般の酸化物が持つ 1.5 〜 1.7 の值に近づく. また $\mathrm{SiO}_{2}$ ガラスについては IR スペクトルの圧力変化からも $\gamma$ が求められており負の 值が報告されている27)。この $\gamma_{\mathrm{e}}$ の組成変化は実験結果 の項で述べた $\mathrm{PbO}$ 導入による $\mathrm{SiO}_{2}$ ガラスの弾性的異 常の消失に一致している. $\mathrm{SiO}_{2}$ ガラスの $\gamma_{\mathrm{e}}$ が負である ということは（10）式において $\mathrm{d} \theta_{3} / \mathrm{d} V>0$ となる。 こ れは圧力をかけると $\theta_{3}$ が減少し，より乱れた構造にな ることを意味しており，このことが $\mathrm{SiO}_{2}$ ガラスの弾性 的異常を引き起こしているのではないかと思われる。一 方 $\mathrm{PbO}$ 導入に伴い $\gamma_{\mathrm{e}}$ は正の值となって弾性的異常は消 失するが,これは $\mathrm{PbO}$ 導入によってガラス構造の乱れ

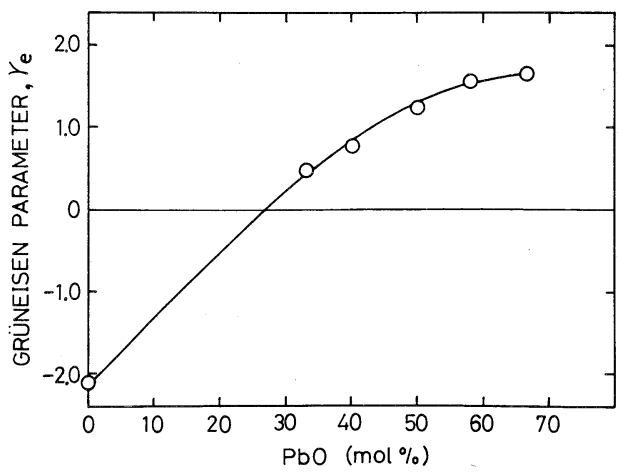

Fig. 11. Grüneisen parameter $\gamma_{\mathrm{e}}$ versus $\mathrm{PbO}$ content for $\mathrm{PbO}-\mathrm{SiO}_{2}$ glasses. 
が減少するため, $\mathrm{d} \theta_{3} / \mathrm{d} V(>0)$ の寄与が少なくなるこ とと, $\mathrm{d} \theta_{\mathrm{E}} / \mathrm{d} V(<0)$ の寄与が増加することによるもの と考えられる. 後者の寄与は, 修飾イオンとして $\mathrm{Pb}^{2+}$ イオンが働くときには $\mathrm{Pb}-\mathrm{O}$ 間の結合は弾性的異常を 消失させる方向に寄与することを意味している．構造論 的に考えると，圧力をかけることによりパッキングが良 くなるが，これは $\mathrm{SiO}_{4}$ 四面体による網目構成環のねじ れなどを伴うため Si-O-Si 角の変動が大きくなり，結 局ガラス構造はより乱れることになる．しかし $\mathrm{SiO}_{2}$ に $\mathrm{PbO}$ を導入することにより $\mathrm{Pb}-\mathrm{O}$ 間の結合ができ，ま た $\mathrm{SiO}_{4}$ 四面体間の空げきが $\mathrm{Pb}^{2+}$ イオンで埋められる ことにより空間的にも $\mathrm{SiO}_{4}$ 四面体網目はねじれにくく なり, Si-O-Si 角の変動が圧力により起こりにくくな るものと解釈される.

前述した圧力係数の組成依存性を更に詳しくみてみる ことにする．図 5 のように $\mathrm{PbO}-\mathrm{SiO}_{2}$ 系と $\mathrm{Na}_{2} \mathrm{O}-\mathrm{SiO}_{2}$ 系のグラフを比較すると, 共に修飾酸化物を添加してい くにつれて $\mathrm{SiO}_{2}$ ガラスの弾性的異常は消失する．体積 弾性率の圧力係数が 0 になる組成を内捜して求めると, $\mathrm{PbO}$ 系では約 $20 \mathrm{~mol} \%, \mathrm{Na}_{2} \mathrm{O}$ 系では約 $16 \mathrm{~mol} \%$ とな る.このときの導入力チオン $\mathrm{Pb}^{2+}, \mathrm{Na}^{+}$はそれぞれ 20 $\mathrm{mol} \%, 32 \mathrm{~mol} \%$ となり，その比は 0.6 である．一方 $\mathrm{Pb}^{2+}$ 及び $\mathrm{Na}^{+}$イオンが網目空げきで占める体積の比は イオン半径の 3 乗の比であるので, $(1.2 / 1.0)^{3}=1 / 0.6$ となり, 導入カチオン数の比のちょうど逆数となる. し たがって体積弾性率の圧力係数を 0 にする導入力チオン のガラス中に占める体積はほぼ同程度になる．このこと は, 添加量が少ないときは $\mathrm{SiO}_{2}$ ガラス中の $\mathrm{Pb}^{2+}, \mathrm{Na}^{+}$ 各イオンの役割は網目空げきを埋めることであって, 根 本的な差異がないことを示しているといえる。しかし $\mathrm{PbO}$ 含有量が $50 \mathrm{~mol} \%$ を超えると体積弾性率の圧力係 数は 7〜8 と正常な一定の值をとるようになる.これは 弾性率の組成依存性の節で述べたように $\mathrm{Pb}^{2+}$ イオンが 網目に組み込まれ, $\mathrm{SiO}_{4}$ 四面体が連続した網目構造が 消失し，上述の $\mathrm{d} \theta_{3} / \mathrm{d} V$ の寄与よりも $\mathrm{d} \theta_{1} / \mathrm{d} V$ の寄与が 大きくなるためと思われる.

弾性率の温度係数は一般的には温度の上昇に伴い試料 が伸びるので圧力係数とは反対の符号をもち, 通常は負 の値をもつ．温度の影響を圧力の場合と同様に考察する ために（9）式を次のように書き換える.

$$
\gamma=\frac{-1}{3 \alpha_{\mathrm{L}} \sum_{i} C_{i}}\left(\sum_{i} \frac{C_{i}}{\theta_{i}} \frac{\mathrm{d} \theta_{i}}{\mathrm{~d} T}\right), \quad(i=1,3, E)
$$

$\mathrm{SiO}_{2}$ ガラスの場合は温度係数が正の值となる弾性的 異常を示すが，Si-O 結合のポテンシャルの非調和性の 点のみからは $\mathrm{Si}-\mathrm{O}$ 結合の原子間距離が温度上昇ととも に長くなるので網目骨格内結合は弱くなり，それに対応 して $\theta_{1}$ も減少し, 結局 $\mathrm{d} \theta_{1} / \mathrm{d} T$ は負になるはずである. したがって $\mathrm{SiO}_{2}$ ガラスの $\gamma$ が負となるためには
式において $\mathrm{d} \theta_{3} / \mathrm{d} T$ が正の值, つまり温度上昇とともに $\theta_{3}$ が大きくなる必要がある。このことは構造論的には 温度上昇により $\mathrm{Si}-\mathrm{O}-\mathrm{Si}$ 角の分布が狭くなり乱れの程 度が低くなることを意味しており, 石英, クリストバラ イト，トリジマイトにみられる低温安定型から，より対 称性の良い高温安定型への転移現象とよく対応している と思われる. また $\mathrm{PbO}$ 含有量が増えるにつれて $\gamma_{\mathrm{e}}$ は負 から正になっていくが，これは圧力変化について考察し たのと同様，(12）式において $\gamma$ への $\mathrm{d} \theta_{3} / \mathrm{d} T$ の寄与が 減少していくためであると考えられる.つまり $\mathrm{PbO}$ 導 入によりガラス構造の乱れが低くなり温度上昇に伴う $\theta_{3}$ の増加の度合は減少していく.

一方，体積弾性率の温度係数を 0 にするのに必要な修 飾酸化物の量は図 6 上り, $\mathrm{PbO}$ は約 $37 \mathrm{~mol} \%, \mathrm{Na}_{2} \mathrm{O}$ は約 $18 \mathrm{~mol} \%$ であり, 両者の導入カチオン比はちょう ビ 1 である. したがって圧力係数について考察したよう な修飾カチオンの空げき充てん効果とは違い, 温度係数 の場合には非架橋酸素の数に関係しているものと思われ るが，その機構は複雑なものと考えられ現在明らかでな い.

\section{4. 総 括}

$\mathrm{PbO}-\mathrm{SiO}_{2}$ 系ガラスの弾性率の組成，圧力及び温度依 存性を調べ次のことが分かった。

（1）音速，ヤング率，剛性率は組成に対してほぼ直 線的に減少し，ポアッソン比も同様の傾向で増加する. しかし体積弾性率は $\mathrm{PbO}$ 含有量が $50 \mathrm{~mol} \%$ 付近で極 大をとった後，急激に減少する．この急激な減少はガラ 又網目骨格の $\mathrm{Si}-\mathrm{O}$ 結合に $\mathrm{Pb}-\mathrm{O}$ 結合が組み込まれるた めに生じたものと考えられる.

( 2 ) $\mathrm{PbO}-\mathrm{SiO}_{2}$ 系ガラスでは $\mathrm{PbO}$ 含有量が増加す るにつれて $\mathrm{SiO}_{2}$ ガラスにみられる弾性的異常は消失 し， $50 \mathrm{~mol} \%$ を超えると正常な一定の正の弾性率圧力 係数及び負の温度係数をもつようになる.

(3) 3-バンド理論による解析から $\mathrm{PbO}-\mathrm{SiO}_{2}$ 系ガラ スの構造の乱れは $\mathrm{PbO}$ 添加とともに減少することが分 かった。また弾性率の圧力及び温度変化はこの構造の乱 れと関係する特性温度の変化をもとに説明することがで きた。

\section{文献}

1) M. Leventhal and P. J. Bray, Phys. Chem. Glasses, 6, 113-25 (1965).

2) T. Yanagase and Y. Suginohara, Trans. Japan. Inst. Metals, 11, 400-03 (1970).

3）那須弘行，吉本 護，大田陸夫，兽我直弘，窯協， 90 , 303-05 (1983).

4）細野秀雄，川副博司，金澤孝文，窯協，90，544-51 (1982).

5) G. J. Bair, J. Am. Ceram. Soc., 19, 339-47 (1936).

6) J. Krogh-Moe, Z. Phys. Chemie, 18, 223-31 (1958). 
7) G. O. Bagdyk'yants and A. G. Alekseev, in "The Structure of Glass", 2, 198-201 (1960).

8) C. Brosset, Phys. Chem. Glasses, 4, 99-102 (1963).

9）安藤淳平, 窯協, 69, 380-83 (1961).

10) M.F. Mydler, N. J. Kreidl, J. K. Hendren and G. J. Clayton, Phys. Chem. Glasses, 11, 196-204 (1970).

11）今岡 稔, 長谷川 洋, 窯協, 88, 141-50 (1980).

12) E. M. Rabinovich, J. Mater. Sci., 11, 925-48 (1976).

13) E. Kordes, Glastech. Ber., 17, 65-71 (1939).

14) H. Hagiwara and R. Oyamada, J. Phys. Soc. Japan, 40, 199-203 (1976)

15) H. H. Demarest, J. Acoust. Soc. America, 49, 768-75 (1971).

16）後藤隆康, 兽我直弘, 㝙協, 91, 24-31 (1983).

17）大田隆夫, 畺我直弘, 功刀雅長, 窯協, 81，156-61 (1973).
18) R. N. Thurston, IEEE Proc., 53, 1320-50 (1973).

19) S. Spinner, J. Am. Ceram.Soc., 39, 113-18 (1956).

20) J. T. Krause and C. R. Kurkjian, J. Am. Ceram. Soc., 51, 226-27 (1968).

21) K. Hirao, N. Soga and M. Kunugi, J. Am. Ceram. Soc., 62, 570-73 (1979).

22) M.H. Manghnani, Proc. of the XIth International Congress on Glass, Kyoto, 11, 104-14 (1974).

23) B. M. J. Smets and T.P.A. Lommen, J. Non-Cryst., Solids, 48, 423-30 (1982).

24) N. Soga, J. Non-Cryst. Solids, 52, 365-75 (1982).

25) J.D. Jorgensen, J. Appl. Phys., 49, 5473-78 (1978).

26) F. Birch, J. Appl. Phys., 9, 279-88 (1938).

27) J. R. Ferraro and M. H. Manghnani, J. Appl. Phys., 43, 4595-99 (1972). 